\title{
Comparative epidemiology of late blight and early blight of potato under different environmental conditions and fungicide application programs
}

\section{Epidemiologia comparativa da requeima e pinta preta da batateira sob diferentes condições ambientais e programas de aplicação de fungicida}

\author{
Henrique da Silva Silveira Duarte ${ }^{1 *}$; Laércio Zambolim²; Franklin Jackson \\ Machado $^{3}$; Hitor Rafael Pereira Porto ${ }^{4}$; Fabrício Ávila Rodrigues ${ }^{2}$
}

\begin{abstract}
Three experiments were carried out in an experimental field from Viçosa city, Minas Gerais, Brazil, to compare late blight (LB) (Phytophthora infestans) and early blight (EB) (Alternaria grandis) epidemics under different environmental conditions and fungicide application programs. Each experiment consisted of two side-by-side trials that were arranged in a randomized complete block design with five treatments and five replications. At 30 days after planting the potato ('Ágata' cultivar) plants in plots of trials 1 and 2 were inoculated with an isolate of $P$. infestans (A2 mating type) and four isolates of $A$. grandis, respectively. Fungicide applications were initiated at seven days after inoculation and repeated at 7- or 15-day intervals. The severity of LB and EB was assessed every two days, and the area under disease progress curve (AUDPC) was calculated for both diseases. The yield was quantified by weighing the tubers of all the plants from each plot after their maturation. Yield data were converted into $\mathrm{kg} \mathrm{ha}^{-1}$ and the percentage of loss was calculated for each treatment. Based on the AUDPC, the LB severity was greater than the EB severity under all three environmental conditions, and this was reflected in the yield. LB and EB caused yield losses as high as of 82 and $45 \%$, respectively. The fungicide effects on both LB and EB and the associated yield losses changed according to the environmental conditions, therefore, indicating the importance of using tools such as a forecast system to help farmers to decide the best time for fungicide application.
\end{abstract}

Key words: Alternaria grandis. Disease control. Foliar disease. Phytophthora infestans. Solanum tuberosum.

\section{Resumo}

Três experimentos foram conduzidos em um campo experimental na cidade de Viçosa, localizada no estado de Minas Gerais, Brasil, para comparar epidemias de requeima (RE) (Phytophthora infestans) e pinta preta (PP) (Alternaria grandis) em diferentes condições ambientais e programas de aplicação

1 Prof., Departamento de Fitotecnia e Fitossanidade, Universidade Federal do Paraná, UFPR, Curitiba, PR, Brasil. E-mail: henriqueduarte@ufpr.br

2 Profs., Departamento de Fitopatologia, Universidade Federal de Viçosa, UFV, Viçosa, MG, Brasil. E-mail: zambolim@ufv.br; fabricio@ufv.br

3 Discente, Curso de Doutorado, Departamento de Fitopatologia, UFV, Viçosa, MG, Brasil. E-mail: franklinjacksonmachado@ gmail.com

4 Eng $^{\circ}$ Agr ${ }^{\circ}$, Departamento de Fitopatologia, UFV, Viçosa, MG, Brasil. E-mail: hrafael89@yahoo.com.br

* Author for correspondence 
de fungicidas. Cada experimento consistiu em dois ensaios lado a lado seguindo um delineamento de blocos casualizados com cinco tratamentos e cinco repetições. Aos 30 dias após o plantio dos tubérculos de batata do cultivar 'Ágata', as plantas das parcelas dos ensaios 1 e 2 foram inoculadas com um isolado de $P$. infestans (grupo de compatibilidade A2) e quatro isolados de A. grandis, respectivamente. As aplicações de fungicida foram iniciadas aos sete dias após a inoculação e repetidas em intervalos de 7 ou 15 dias. A severidade da RE e PP foi avaliada a cada dois dias e a área abaixo da curva de progresso da doença (AACPD) foi calculada para ambas as doenças. A produtividade foi quantificada pesando os tubérculos de todas as plantas de cada parcela após a maturação. Produtividade foi convertida para $\mathrm{kg}$ $\mathrm{ha}^{-1} \mathrm{e}$ a percentagem de redução da produtividade foi determinada para cada tratamento. Com base na AACPD, a severidade da RE foi maior que a severidade da PP nas três condições ambientais e refletiu na produtividade. A redução de produtividade foi de até 82 e $45 \%$ para RE e PP, respectivamente. A eficiência dos fungicidas no controle de RE e PP e as reduções na produtividade mudaram de acordo com o ambiente, indicando, portanto, a importância de usar ferramentas como um sistema de previsão para ajudar os agricultores a decidir o melhor momento para a aplicação de fungicidas.

Palavras-chave: Alternaria grandis. Controle de doença. Doença foliar. Phytophthora infestans. Solanum tuberosum.

\section{Introduction}

Potatoes (Solanum tuberosum L.) are an important food crop that are cultivated in more than one hundred countries. In 2017, the global potato production was estimated at 388 tons, and the Brazilian potato production was estimated at 3.7 million tons (FAO, 2019). Potato production is limited by several factors, including the occurrence of diseases. Diseases that affect potato production include the late blight, caused by Phytophthora infestans (Mont.) de Bary, and the early blight, caused by Alternaria grandis E.G. Simmons, are considered to be of great importance.

Late blight occurs in all Brazilian regions that cultivate potatoes. High humidity and moderate temperatures $\left(10\right.$ to $\left.22^{\circ} \mathrm{C}\right)$ favor disease development (MAZIERO et al., 2009). When control measures fail, late blight epidemics may destroy an entire production field in a few days. Temperatures over 30 ${ }^{\circ} \mathrm{C}$ can slow or stop disease development however, the pathogen may remain alive in the host tissues, and may be stimulated and cause damage as soon as the climatic conditions become favorable (LIMA et al., 2009). Lesions occur on the leaves, stems, and tubers, which can be observed at any plant growth stage (ZAMBOLIM et al., 2011). The population of P. infestans in Brazil consists of two clonal lineages: US-1 is associated with tomatoes (A1 mating type) and BR-1 (A2 mating type) is associated with potatoes. Isolates of the BR-1 clonal lineages are more aggressive to potato cultivars than to tomato cultivars, indicating a significant host-specificity (SUASSUNA et al., 2004).

Early blight is favored by high humidity and high temperatures $\left(18\right.$ to $\left.30^{\circ} \mathrm{C}\right)$; it usually destroys the crop completely if control measures are not implemented at the right time (ADAMS; STEVENSON, 1990; CARDOSO, 2010). The disease causes necrotic lesions on the leaves, stems, and tubers (ROTEM, 1994). These lesions can be observed at any stage of the development of the plant. The damage is most severe in mature and senescent tissues (DITA-RODRIGUEZ et al., 2006; JOHNSON; TENG, 1990). At high severity, the disease destroys the leaves, causing defoliation, and decreases yield and the quality of the tubers (CASTRO et al., 2000). The mitosporic fungus Alternaria solani Sorauer has been named as the causal agent of the disease (ROTEM, 1994). However, in a review of the genus Alternaria based on morphological studies, A. tomatophila E.G.Simmons was reported to be the causal agent of early blight in tomatoes and $A$. solani was the causal agent of early blight in potatoes (SIMMONS, 2000). Recent studies in Brazil have revealed the widespread occurrence of $A$. grandis and $A$. 
tomatophila, which cause early blight in potatoes and tomatoes, respectively. Interestingly, in the same study, isolates of $A$. solani were not detected as causing early blight in potatoes (RODRIGUES et al., 2010). Nevertheless, the symptoms of foliar early blight caused by $A$. grandis are similar to those caused by $A$. solani.

Despite the impact of both late blight and early blight on potato production, there have been no comparative epidemiological analyses of these diseases under different environmental conditions. Comparative epidemiology looks at similarities and differences among epidemics (KRANZ, 1988). These studies tend to emphasize the temporal dynamics of plant diseases, most likely because their progress is often the most easily viewed manifestation of infection. When performing temporal analyses of plant diseases, the progress curve is the best representation of an epidemic. Interpreting the shape of these curves and determining certain parameters, such as the area under disease progress curve (AUDPC), are of critical importance to provide a better understanding of the behavior of epidemic and to develop effective disease management strategies (DUARTE et al., 2012).

The regular application of protectant and systemic fungicides is the most important strategy for the control of both late and early blight, since it is very effective (AYLOR et al., 2001; GUENTHNER et al., 1999; MIZUBUTI, 2001; SHUMAN; CHRIST, 2005; TÖFOLI et al., 2003). Normally, applications of fungicide to control these diseases follow a calendar-based schedule, with predefined application intervals. In order to determine whether the schedule is appropriate, it would be useful to know the effectiveness of different fungicides at controlling early blight and late blight on potatoes under different environmental conditions.

The effect of late blight on potato yield is known to be greater at moderate temperatures, while the early blight causes greater damage at warmer temperatures. In recent years, the severity of early blight in potato fields has increased. However, the potential damage from both late blight and early blight under different environmental conditions in Brazil remains unknown.

The present study aimed to compare epidemics and damage of both late blight and early blight of potato under different environmental conditions and fungicide application programs in Brazil.

\section{Material and Methods}

Field experiments, treatments, and inoculations

Three experiments were carried out in an experimental field at the Universidade Federal de Viçosa, Viçosa city, which is located in the southeast portion of the state of Minas Gerais, Brazil, at $20^{\circ} 44^{\prime} 44^{\prime \prime} \mathrm{S}, 42^{\circ} 50^{\prime} 59^{\prime \prime} \mathrm{W}$, and $661 \mathrm{~m}$ above sea level. The experiments 1, 2, and 3 were conducted from April $4^{\text {th }}$ to June $29^{\text {th }}$ (from early autumn to early winter), May $30^{\text {th }}$ to September 3 rd (from late autumn to late winter), and August $3^{\text {rd }}$ to October $28^{\text {th }}$ (from mid-winter to mid-spring), respectively. In each experiment, there were two side-by-side trials, one for late blight (Trial 1) and the other for early blight (Trial 2); 'Ágata', an early-foliage-maturing cultivar that is susceptible to both late blight and early blight (DUARTE et al., 2012, 2014), was used in all experiments. Each plot consisted of three rows measuring $4.0 \mathrm{~m} \times 2.4 \mathrm{~m}$, with $2.5 \mathrm{~m}$ alleyways between adjacent plots.

For each trial, the experimental design was a randomized block with five treatments and five replications. In trial 1 , the treatments were: 1) a negative control (without a late blight fungicide application); 2) weekly application of chlorothalonil (Daconil $\mathrm{BR}^{\circledR}$ ) at a rate of $1.3 \mathrm{Kg}$ of ai ha-1; 3) biweekly application of a premixed solution of metalaxyl + mancozeb (Ridomil Gold $\mathrm{MZ}^{\circledR}$ ) at $0.1+1.6 \mathrm{Kg}$ ai ha ${ }^{-1}$, respectively; 4) weekly alternated application of metalaxyl + mancozeb or chlorothalonil at the rates described in the respective 
treatments 2 and $3 ; 5$ ) application of a premixed solution of dimethomorph + chlorothalonil (Forum Plus $^{\circledR}$ ) at $0.2+1.0 \mathrm{Kg}$ of ai ha ${ }^{-1}$, respectively, every two days and tebuconazole $\left(\right.$ Folicur $^{\circledR}$ ) at $0.3 \mathrm{Kg}$ of ai ha ${ }^{-1}$ every three days. Treatment 5 was used to achieve maximum disease control and to estimate potato yield in the absence of late blight and early blight. All fungicide applications were initiated at 37 days after planting (DAP), except for treatment 5 for which the first application occurred at 30 DAP. The final applications were made when plants reached their maturity.

In trial 2, the treatments were: 1) negative control (without an early blight fungicide application); 2) weekly application of chlorothalonil (Daconil $\mathrm{BR}^{\circledR}$ ) at the rate of $1.3 \mathrm{Kg}$ of ai ha-1; 3) biweekly application of tebuconazole $\left(\right.$ Folicur $\left.^{\circledR}\right)$ at $0.3 \mathrm{Kg}$ of ai ha- ${ }^{-1}$ 4) weekly alternated application of tebuconazole and chlorothalonil at the rates described in treatments 2 and 3 ; 5) application of a premixed solution of dimethomorph + chlorothalonil (Forum Plus ${ }^{\circledR}$ ) at $0.2+1.0 \mathrm{Kg}$ of ai ha-1 ${ }^{-1}$, respectively, every two days and tebuconazole $\left(\right.$ Folicur $^{\circledR}$ ) at $0.3 \mathrm{Kg}$ of ai ha ${ }^{-1}$ every three days. Treatment 5 was again used to achieve maximum disease control and to estimate potato yield in the absence of late blight and early blight. Treatments 2, 3, and 4 were initiated at 37 DAP, while treatment 5 was initiated at 30 DAP. The final applications were made when plants reached their maturity.

In trial 1, all plots, except for those receiving treatment 5, were artificially inoculated at 30 DAP with A2 mating type and mitochondrial haplotype Ib (mtDNA) isolates of $P$. infestans (OLIVEIRA, 2010) collected from Maria da Fé, Minas Gerais. In trial 2, all plots, except for those receiving treatment 5 , were artificially inoculated at 30 DAP with a mixture of equal proportion of four isolates of $A$. grandis collected from different potato-growing regions of Brazil (cities of Camanducaia, MG; Cristalina, GO; Bom Repouso, MG; and Bueno Brandão, MG). For both pathogens, a concentration of 200 sporangia and 200 conidia per $\mathrm{mL}$ was used, and plants from each plot were inoculated using a backpack sprayer equipped with a cone nozzle and a pressure-regulating valve adjusted to obtain a working pressure of $30 \mathrm{lbf} . \mathrm{in}^{-2}$.

\section{General crop management and weather monitoring}

In addition to the assigned treatments listed above for trials 1 and 2, plants from all plots were treated with chlorothalonil (Daconil $\mathrm{BR}^{\circledR}$ ) at 10,15 , and $20 \mathrm{DAP}$ at $1.3 \mathrm{Kg}$ of ai ha- ${ }^{-1}$ to minimize natural infections such as late and early blight development prior to artificial infection. In addition, plants from plots receiving treatment 1 (negative control) or early or late blight specific treatments $(2,3$, and 4) were also treated with tebuconazole (Folicur $\left.{ }^{\circledR}\right)$ in Trial 1 at $0.3 \mathrm{Kg}$ of ai ha-1 every three days to reduce the chance of early blight developing and interfering with the results in the late blight trial, and with dimethomorph $\left(\right.$ Forum $^{\circledR}$ ) in Trial 2 at 0.4 $\mathrm{Kg}$ of ai ha ${ }^{-1}$ at two-day intervals to minimize risk of late blight developing and interfering with the results in the early blight trial.

Plants were fertilized with ammonium sulphate, superphosphate, and potassium chloride at planting at a rate of $38: 420: 150 \mathrm{Kg} \mathrm{ha}^{-1} \mathrm{~N}: \mathrm{P}_{2} \mathrm{O}_{5}: \mathrm{K}_{2} \mathrm{O}$. They were hilled and fertilized again with ammonium sulphate (152 Kg N ha') at 25 DAP. Tubers were planted at distances of 0.19 to $0.44 \mathrm{~m}$, depending on their diameter, to obtain 15 stems $\mathrm{m}^{-2}$. Sprinkler irrigation was used over the entire experimental area. The herbicide metribuzin $\left(\right.$ Sencor $^{\circledR}$ ) was applied at planting using a backpack sprayer with a fan tip at a rate of $0.30 \mathrm{Kg}$ of ai ha-1 using a pressure-regulating valve to obtain a $30 \mathrm{lb}$ inch $^{-2}$ working pressure. The insecticides cipermetrina + profenofos $\left(\right.$ Polytrin $^{\circledR}$ ) and abamectina (Vertimec $18 \mathrm{CE}^{\circledR}$ ) were applied to the foliage at rates of $0.35 \mathrm{Kg}$ of ai ha ${ }^{-1}$ and $58 \mathrm{~g}$ of ai ha ${ }^{-1}$, respectively, using a backpack sprayer with a conical tip and a pressure-regulating valve to obtain a $30 \mathrm{lb}^{\mathrm{inch}}{ }^{-2}$ working pressure. 
The climate variables measured were precipitation (rain plus irrigation); maximum, average, and minimum relative humidity $(\mathrm{RH})$; and maximum, average, and minimum temperature. These measurements were taken using a meteorological station (Squitter, Squitter Soluções em Monitoramento Ambiental, São José dos Campos, São Paulo, Brazil) located in the field and equipped with sensors programmed to collect data. The temperature and RH sensors were located above the potato canopy, approximately $1.50 \mathrm{~m}$ above the ground. Data was collected every 15 minutes and summarized to generate the percentage of favorable time for each disease during the epidemics that were obtained dividing the total number of favorable time by total time and multiplied by 100 . A 15 minute time segment was considered favorable for late blight when temperature was between 10 and $22{ }^{\circ} \mathrm{C}$ (MAZIERO et al., 2009) with a RH of above $85 \%$ (ANDRADE-PIEDRA et al., 2005), and favorable for early blight at temperatures between 18 and 30 ${ }^{\circ} \mathrm{C}$ (CARDOSO, 2010) with a RH of above $85 \%$ (ANDRADE-PIEDRA et al., 2005).

\section{Disease assessment, yield, and data analysis}

Late blight and early blight severities on plants from each plot were quantified every two days, from 30 to 70 DAP, using a descriptive key (JAMES, 1971) with a few modifications (FRY et al., 1977) and a standard area diagram set (DUARTE et al., 2013), respectively. Potato yields of the experiments were assessed by weighing the tubers of all the plant from each plot after their maturation. Yield data were converted into $\mathrm{kg} \mathrm{ha}^{-1}$.

Disease severity data were plotted to obtain the disease progress curves, and the AUDPC was calculated using the methods of Shaner and Finney (1977). The 95\% confidence interval was then determined for each treatment. The percentage of control for each treatment was calculated using the formulae: (AUDPC value of treatment 1 - AUDPC value of each treatment)/AUDPC value of treatment 1) $\times 100$. The $95 \%$ confidence interval for the potato yield was determined for each treatment. The percentage of loss was calculated by dividing the yield of each treatment by the yield of treatment 5 $\times 100$.

\section{Results}

\section{Meteorological data}

In experiment 1 , the temperature during the epidemic ranged from 6.2 to $28.3^{\circ} \mathrm{C}$ with an average temperature of $16.7^{\circ} \mathrm{C}$ (Figure 1a). The $\mathrm{RH}$ ranged from 38.6 to $98.5 \%$ (data not shown) with an average $\mathrm{RH}$ of $86.2 \%$ (Figure 1a). The total precipitation was $102.8 \mathrm{~mm}$ (Figure 1a). The percentage of time that the conditions were climatically favorable to late blight was $57.5 \%$, compared with early blight (7.1\%), during the epidemic.

In experiment 2, the temperature during the epidemic ranged from 4.1 to $30.1^{\circ} \mathrm{C}$ with an average temperature of $15.5^{\circ} \mathrm{C}$ (Figure $1 \mathrm{~b}$ ). The $\mathrm{RH}$ ranged from 36.0 to $98.4 \%$ (data not shown) with an average RH of $85.6 \%$ (Figure 1b). The total precipitation was $119.0 \mathrm{~mm}$ (Figure 1b). The percentage of time that the conditions were climatically favorable to late blight was $49.5 \%$, compared with early blight $(2.34 \%)$, during the epidemic.

In experiment 3 , the temperature during the epidemic ranged from 5.0 to $32.6{ }^{\circ} \mathrm{C}$ with an average temperature of $18.4{ }^{\circ} \mathrm{C}$ (Figure 1c). The RH ranged from 28.9 to $97.5 \%$ (data not shown) with an average RH of $77.6 \%$ (Figure 1c). The total precipitation was $365.8 \mathrm{~mm}$ (Figure 1c). The percentage of time that the conditions were climatically favorable to late blight was $38.5 \%$, compared with early blight $(6.2 \%)$, during the epidemic. 
Figure 1. Values of meteorological variables recorded during the epidemics in experiments 1 (a), 2 (b), and 3 (c). Average relative humidity is represented by a dotted line with empty circles, pluviometric precipitation by vertical bars and temperature by a solid line. Maximum, medium, and minimum temperatures are represented by $\rightarrow-\rightarrow$, $\rightarrow-\rightarrow$ and $\rightarrow-\rightarrow$, respectively.

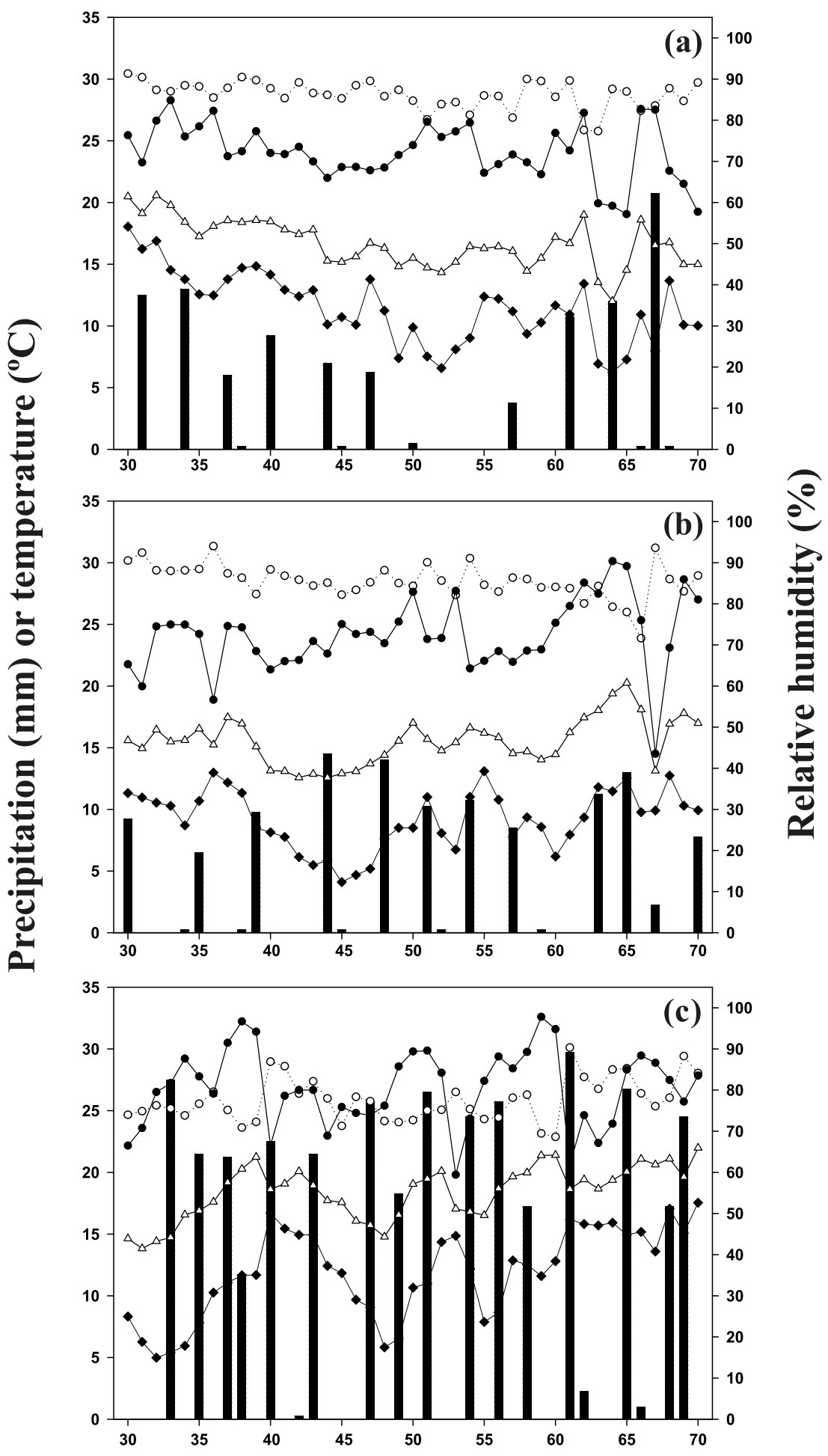

Days after planting 
Disease progress, AUDPC, and potato yield

In experiment 1, late blight and early blight epidemics started at 34 and 36 DAP, respectively. Late blight severity on plants from plots that did not receive fungicide reached $100 \%$ at $50 \mathrm{DAP}$, and early blight severity on plants from plots without fungicide application reached $82 \%$ at 70 DAP. Late blight severity on plants from plots that received fungicides reached $100 \%$ at 52,54 , and 56 DAP for treatments 2, 3, and 4, respectively. However, on plants from plots on which fungicides were applied, early blight severity at 70 DAP was 38,29 , and $18 \%$ for treatments 2, 3 and 4, respectively.

The progress curves of each treatment in experiment 1 , except for treatment 5 in which there was no disease on plants, are shown in Figure 2a. Plants from plots that received treatment 5 (healthy plants) reached maturity at 87 DAP. The AUDPC for plants from the plots that did not receive fungicides application to control late blight (treatment 1, trial 1) was greater than the AUDPC for plants from plots that did not receive fungicides to control early blight (treatment 1, trial 2) (Table 1). Late blight and early blight resulted in yield losses of 82 and $45 \%$, respectively (Table 2). In the trial 1 , despite the fact that the AUDPC for treatments 2, 3, and 4 were lower than AUDPC for treatment 1, the percentage of late blight control was very low $(<6 \%)$ (Table 1). Notably, the plants in treatments 2,3 , and 4 had the same yields as the plants in treatment 1 , and the losses were greater than $81 \%$ (Table 2).

In trial 2, the AUDPC for plants from treatments 2,3 , and 4 were lower in comparison to treatment 1 , and the control percentage was greater than $62 \%$. Treatment 4 was the most efficient at controlling early blight, and resulted in lower AUDPC and the highest control percentage, followed by treatments 3 and 2 (Table 1). The yields of plants from treatments 2,3 , and 4 were higher than treatment 1 , and losses were less than $35 \%$ (Table 2). In experiment 2, late blight and early blight epidemics started at 36 DAP. Late blight severity on plants from plots on which no fungicides had been applied reached $100 \%$ at $58 \mathrm{DAP}$, and early blight severity on plants from plots that received no fungicide application reached $39 \%$ at 70 DAP. In plots that had fungicides applied to control late blight, the severity at 70 DAP was 99,100 , and $94 \%$ for treatments 2,3 , and 4 , respectively. However, in plots on which fungicides were applied to control the early blight, severity at 70 DAP was 12,10 , and $7 \%$ for treatments 2,3 , and 4 , respectively. The progress curves for each treatment for experiment 2, except for treatment 5 in which there was no disease on plants, are shown in Figure 2b. Plants on plots that received the treatment 5 (healthy plants) reached maturity at 96 DAP. The AUDPC for plants from plots where fungicides were not applied to control late blight (treatment 1, trial 1) was greater than AUDPC for plants from plots where fungicides were not applied to control early blight (treatment 1 , trial 2; Table 1). Late blight and early blight resulted in yield losses of $76 \%$ and $31 \%$, respectively (Table 2 ). In trial 1, the AUDPC for plants from treatments 2, 3, and 4 were lower than treatment 1 , and the control percentage was less than $36 \%$ (Table 1). There were no differences among treatments 2,3 , and 4 regarding yield, which were higher than treatment 1 , and the yield losses were greater than 53\% (Table 2 ). In trial 2, the AUDPC for plants from treatments 2, 3, and 4 were lower than treatment 1 , and the control percentage was greater than 53\% (Table 1). Treatment 4 was the most effective at controlling early blight, as indicated by the lower AUDPC; it also had the highest value for the control percentage, followed by treatments 3 and 2 (Table 1). The yield of plants from treatments 2, 3, and 4 was higher compared to treatment 1 , and yield losses were less than $19 \%$ (Table 2). 
Figure 2. Progress curves of late blight and early blight for plants on the treatments used in the experiments 1 (a), 2 (b) and 3 (c). For trial 1 (late blight), the treatments were: 1 - without fungicide application; 2 - chlorothalonil weekly; 3 - metalaxyl + mancozeb biweekly; 4 - metalaxyl + mancozeb and chlorothalonil weekly alternate. For trial 2 (early blight), the treatments were: 1 - without fungicide application; 2 - chlorothalonil weekly; 3 - tebuconazole biweekly; 4 - tebuconazole and chlorothalonil weekly alternate. Vertical bars represent the standard deviation of the means.
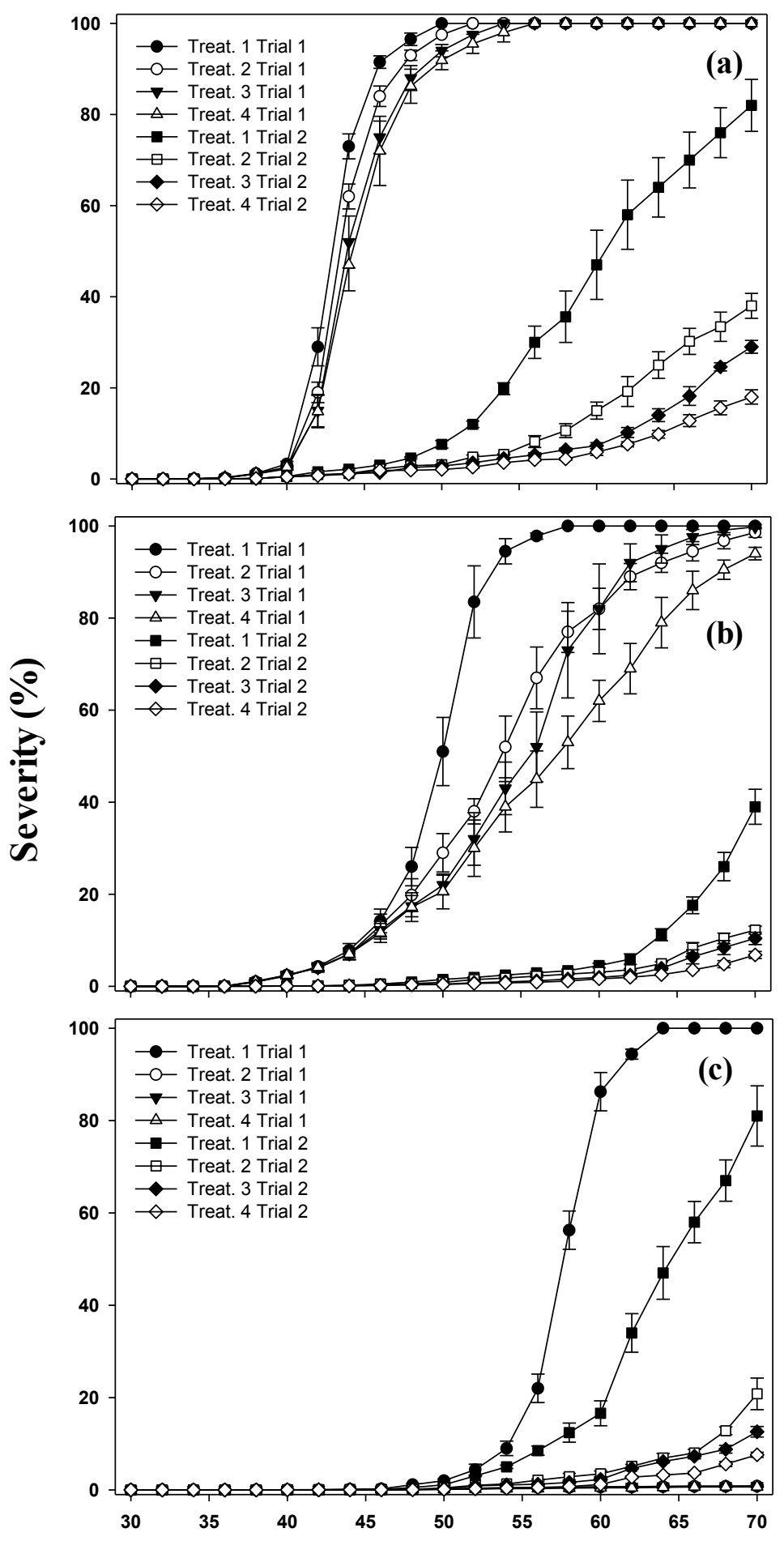

Days after planting 

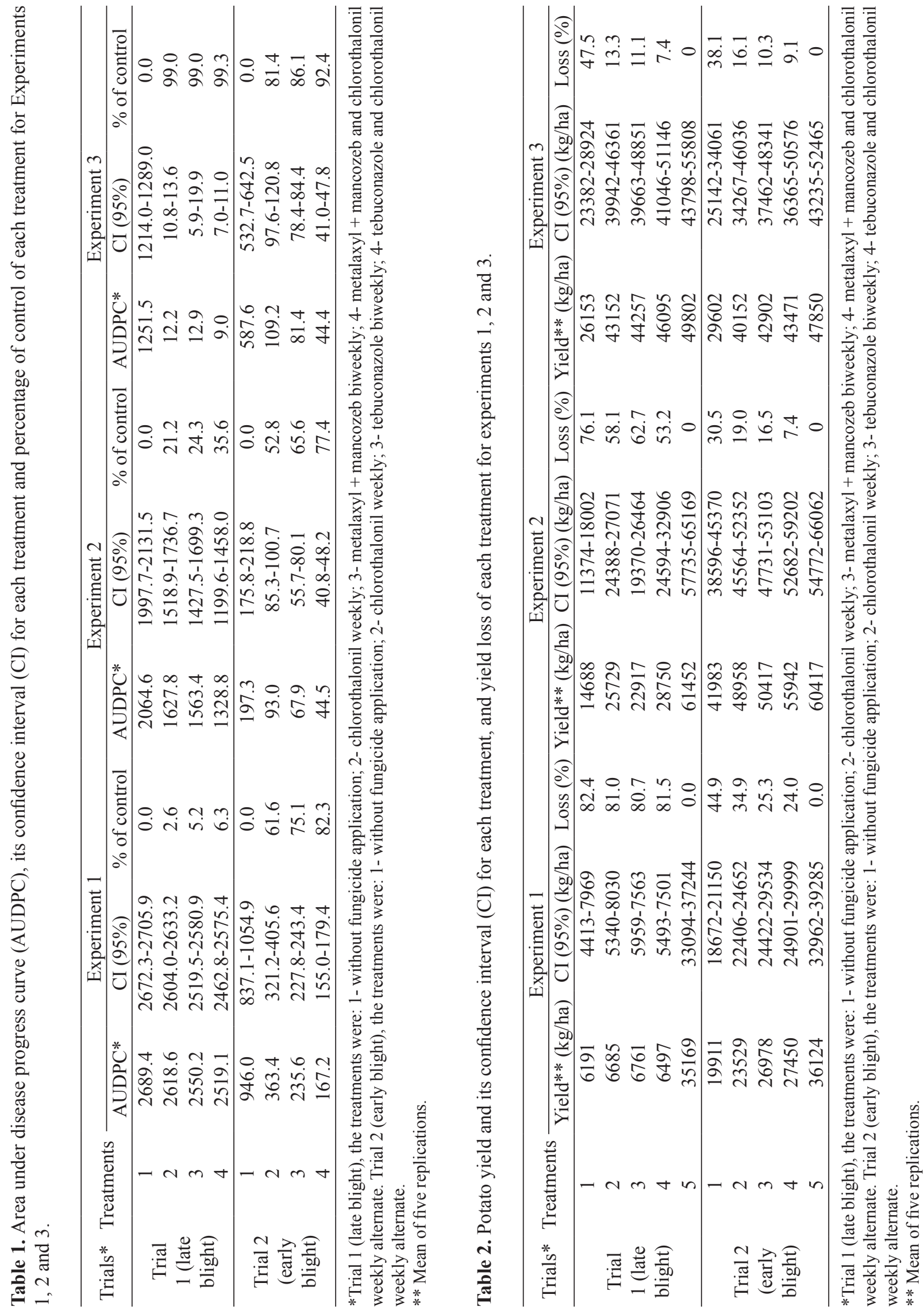
In experiment 3, the late blight and early blight epidemics started 40 DAP. Late blight severity for plants from plots without fungicide application reached $100 \%$ at $64 \mathrm{DAP}$, and early blight severity for plants from plots without fungicide application reached $81 \%$ at 70 DAP. In plots where fungicides were applied to control late blight, the severity at 70 DAP was $0.8,0.9$, and $0.7 \%$ for treatments 2,3 , and 4 , respectively. However, in the plots where fungicides were applied to control early blight, the severity at 70 DAP was 21,13 , and $8 \%$ for treatments 2, 3, and 4, respectively. The progress curves for every treatment of experiment 3, except for treatment 5 in which there was no disease on plants, are shown in Figure 2c. Plants from plots that received the treatment 5 (healthy plants) reached maturity at 86 DAP. The AUDPC for plants from plots where the fungicides were not applied to control late blight (treatment 1, trial 1) were greater than AUDPC for plants from plots where the fungicides were not applied to control early blight (treatment 1, trial 2) (Table 1). Late blight and early blight caused yield losses of 48 and $38 \%$, respectively (Table 2 ). In trial 1 , there were no difference among treatments 2, 3, and 4 for AUDPC and yield, but these treatments differed from treatment 1 . The percentages of control of late blight for treatments 2, 3, and 4 were higher than $99 \%$, and losses were less than $13 \%$ (Tables 1 and 2). There were no differences among treatments 2, 3, and 4 and regarding yield, which was higher than treatment 1 , and the losses were less than $13.3 \%$ (Table 2). For trial 2, AUDPC for plants from treatments 2, 3, and 4 were lower than treatment 1 and the percentage of control was greater than $81 \%$ (Table 1). Treatment 4 was the most effective at controlling early blight, as indicated by the lower AUDPC and the highest control percentage, followed by treatments 3 and 2 (Table 1). There were no differences among treatments 2,3 , and 4 for yield, which was higher than treatment 1 and losses were less than $16 \%$ (Table 2).

\section{Discussion}

Results from the present study are consistent with those reported in the literature regarding the impact of climatic conditions on the development of disease epidemics. In the three climatic conditions evaluated in the present study, late blight epidemics developed faster, compared to early blight, based on the AUDPC. This therefore showed that the conditions trialed were more favorable for late blight than for early blight.

The relationship between climatic conditions and the development of the disease epidemics was also observed when comparing both diseases under different environmental conditions. The conditions in experiment 1 were most favorable for late blight development, followed by those occurring in experiment 2, and then those in experiment 3. For early blight, the conditions were more favorable in experiment 1 , followed by experiments 3 and 2. The temperature ranges and the RH threshold used to calculate the percentage of time that the conditions were climatically favorable to late blight and early blight during the epidemic for each experiment were appropriate for evaluating the different climatic conditions. The percentage of time that the conditions were climatically favorable to late blight was 58, 50, and $39 \%$ for experiments 1,2 and 3, respectively; this shows the same trend as the AUDPC, which indicated that the conditions were most favorable for late blight in experiment 1 , followed by experiments 2 and 3 . The percentage of time that the conditions were climatically favorable to early blight were 7,2 , and $6 \%$ for experiments 1,2 and 3, respectively, showing the same trend as the AUDPC; this shows that the conditions were most favorable to early blight in experiment 1 , followed by experiments 3 and 2 . The temperature (values ranging from 10 to $22^{\circ} \mathrm{C}$ ) used to calculate the percentage of time that the conditions were favorable to the development of late blight was obtained from Maziero et al. (2009). In this 
temperature range, bigger lesions were observed when isolates of $P$. infestans belonging to mating type A2 were used. The temperature range (from 18 to $30^{\circ} \mathrm{C}$ ) used to evaluate the favorability of early blight was obtained from Cardoso (2010). In this temperature range, bigger lesions were observed when isolates of $A$. grandis were used. An RH of $85 \%$ for both diseases was used because this is the threshold required to estimate leaf wetness duration when the RH sensor is located above the canopy of potato plants (ANDRADE-PIEDRA et al., 2005).

Because the impact of late blight is normally more severe than that of early blight, it has become of great concern to potato farmers. Late blight causes the death of plants in a few days and total yield loss if the symptoms appear soon after the emergence of plants under environmental conditions that are favorable for disease development. Therefore, farmers begin fungicide applications soon after plant emergence. Fungicides used to control late blight are formulated in three ways: a) protectant fungicide only, such as chlorothalonil and mancozeb; b) systemic fungicide combined with protectant fungicide, such as dimethomorph + chlorothalonil, metalaxyl-M + mancozeb, cimoxanil + mancozeb, and mandipropamid + chlorothalonil; and c) systemic fungicide only, such as dimethomorph, propamocarb hydrochloride, mandipropamid, metalaxyl-M, fluazinam, and propineb. Most farmers control late blight by using protectant fungicides, systemic fungicides combined with protectant fungicides, and systemic fungicides such as fluazinam and propineb, which are effective for both late blight and early blight; therefore, early blight is controlled indirectly. As a result, early blight is less severe, but increases in severity as the plant tissues get older because mature and senescent tissues are more susceptible (DITA-RODRIGUEZ et al., 2006; JOHNSON; TENG, 1990). Therefore, this disease only becomes a problem during the final crop cycle. The results from the present study indicated that the severity of early blight on plants that did not receive fungicide application can reach high values even before the start of senescence. When farmers use systemic fungicides that only control late blight, such as dimethomorph, propamocarb hydrochloride, mandipropamid, and metalaxyl-M, and do not use a product that specifically controls early blight, the early blight severity can reach the highest values as determined by the present study. This can be explained by the fact that plants used in this study were inoculated at 30 DAP; however, in the field, early blight epidemics can start at seedling emergence due to the presence of $A$. grandis inoculum. If farmers use overlapping cultivation, where new planting is done in areas close to crops in the final cycle, the conidia of $A$. grandis can cause lesions on plants after emergence; this can therefore increase the duration of the epidemic. Another problem that results from using only a systemic fungicide is the increase on the risk of selection of resistant isolates of the pathogen.

To compare late blight and early blight epidemics under different environmental conditions, the day of inoculation and the end of the evaluations were standardized. All the plants in the experiments were inoculated at 30 DAP, because the 'Ágata' cultivar typically reaches the maximum number of stems per plant at approximately 30 DAP under mild or cold temperature conditions (MELO et al., 2003). All plants used in the experiments were evaluated until 70 DAP; which is the point when the leaf area index and the number of leaves of the 'Ágata' cultivar typically decline rapidly due to the ageing of the lower leaves under mild temperature and cold temperature conditions (MELO et al., 2003). Therefore, it is difficult to differentiate disease from senescent plant tissue.

The experiments were carried out from March to October in a low altitude region with low to mild temperatures, which is well suited to growing potatoes. Potato cultivation during the period from October to February, when temperatures are higher, is usually practiced at high altitudes ( $>1000$ meters above sea level), where the temperatures are lower. Therefore, a fourth experiment was carried out 
in the same area as the three other experiments (regions at low altitude) to determine whether potatoes can be grown in the October-February period. Planting was undertaken in late October; the plants reached maturity at 55 DAP due to periods of high temperatures; this indicates, therefore, that they became senescent quickly. Therefore, it was not possible to compare late blight and early blight epidemics in experiment 4.

In the three climatic conditions evaluated, late blight resulted in the greater yield losses than early blight, because late blight epidemics developed more rapidly than early blight. Late blight can cause yield losses of $100 \%$ when disease severity reaches high levels prior to tuberization (DUARTE et al., 2008). In the present study, yield losses of $82.4 \%$ were observed because the 'Ágata' cultivar typically begins the tuberization process at approximately 35 DAP (MELO et al., 2003). This occurred when late blight severity was very low, due to the inoculation with $P$. infestans that occurred at 30 DAP. An early blight epidemic can reduce tuber yield by more than 20\% (JOHNSON; TENG, 1990; SHTIENBERG et al., 1996), and yield losses of approximately 58\% have been reported in Brazil (ARANA et al., 2007). In the present study, maximum yield loss was $44.9 \%$.

The efficiency of the fungicides applied following a calendar schedule with the aim of controlling late blight and early blight was different for each environmental condition, according to the AUDPC. For example, the AUDPC was greater than 2519.1 for experiment 1, when fungicides were used to control late blight; in experiment 3 , it was lower than 12.9, which indicates that the effectiveness of control by fungicides is influenced by the environmental conditions. When a calendar schedule is used, the intervals of fungicide applications are fixed independently of the environmental conditions, creating problems in achieving acceptable diseases control. Considering the conditions that favor rapid disease development, the pre-determined application interval might be longer than necessary to control the disease, and this causes the control measure to fail. In contrast, the pre-determined application interval might be shorter than needed for effective disease control if conditions that are less favorable or unfavorable for disease development; this results in higher fungicide costs than necessary. Forecast systems can be used as tools to help manage the disease and rationalize fungicide use (GLEASON et al., 1995). Such systems are based on meteorological data and aim to identify periods that are favorable for disease development, and to determine when to begin fungicide application, and how often to apply them, on that basis.

Given that both late blight and early blight can cause great yield losses of potatoes, it is important to use the most effective control measures. The efficiency of fungicides applied at pre-determined intervals is dependent on environmental conditions; this indicates the importance of using tools such as a forecast systems to help to farmers decide the best time for fungicide application.

\section{Conclusions}

Late blight severity was greater than early blight severity under all three environmental conditions, and this was reflected in the yields. Late blight and early blight caused yield losses as high as of 82 and $45 \%$, respectively. Fungicide effects on both late blight and early blight and associated yield losses changed depending on the environmental conditions.

\section{Acknowledgements}

The authors thanks the 'Conselho Nacional de Desenvolvimento Científico e Tecnológico' (CNPq) for the fellowship granted to the first, second, and sixth authors. This study was financed in part by the Coordenação de Aperfeiçoamento de Pessoal de Nível Superior - Brasil (CAPES) - Finance Code 001 . 


\section{References}

ADAMS, S. S.; STEVENSON, W. R. Water management, disease development and potato production. American Journal of Potato Research, v. 67, n. 1, p. 3-11, 1990. DOI: $10.1007 / \mathrm{BF} 02986908$

ANDRADE-PIEDRA, J. L.; HIJMANS, R. J.; JUÁREZ, H. S.; FORBES, G. A.; SHTIENBERG, D.; FRY, W. E. Simulation of potato late blight in the Andes. II: validation of the LATEBLIGHT model. Phytopathology, Saint Paul, v. 95, n. 10, p. 1200-1208, 2005. DOI: 10.1094/ PHYTO-95-1200

ARANA, R. O. C.; ZAMBOLIM, L.; COSTA, L. C. Potato early blight epidemics and comparison of methods to determine its initial symptoms in a potato field. Revista Facultad Nacional de Agronomía, Medellin, v. 60, n. 2, p. 3877-3890, 2007.

AYLOR, D. E.; FRY, W. E.; MAYTON, H.; ANDRADE PIEDRA, J. L. Quantifying the rate of release and escape of Phytophthora infestans sporangia from a potato canopy. Phytopathology, Saint Paul, v. 91, n. 12, p. 11891196, 2001. DOI: 10.1094/PHYTO.2001.91.12.1189

CARDOSO, C. R. Agressividade de Alternaria tomatophila, A. grandis e A. solani em Batateira $e$ Tomateiro. 2010. Dissertação (Mestrado em Fitopatologia) - Universidade Federal de Viçosa, Viçosa, MG.

CASTRO, M. E. A.; ZAMBOLIM, L.; CHAVES, G. M.; CRUZ, C. D.; MATSUOKA, K. Variabilidade patogênica de Alternaria solani, agente causal da pinta-preta do tomateiro. Summa Phytopathologica, Botucatu, v. 26, n. 1, p. 24-28, 2000.

DITA-RODRIGUEZ, M. A.; BROMMONSCHENKEL, S. H.; MATSUOKA, K.; MIZUBUTI, E. S. G. Components of resistance to early blight in four potato cultivars: effect of leaf position. Journal of Phytopathology, Berlin, v. 154, n. 4, p. 230-235, 2006. DOI: 10.1111/j.1439-0434.2006.01089.x

DUARTE, H. S. S.; ZAMBOLIM, L.; CAPUCHO, A. S.; NOGUEIRA JUNIOR, A. F.; ROSADO, A. W. C.; CARDOSO, C. R.; MIZUBUTI, E. S. G.; PAUL, P. A. Development and validation of a set of standard area diagrams to estimate severity of potato early blight. European Journal of Plant Pathology, v. 137, n. 2, p. 249-257, 2013. DOI: 10.1007/s10658-013-0234-3

DUARTE, H. S. S.; ZAMBOLIM, L.; MIZUBUTI, E. S. G.; PADUA, J. G.; RIBEIRO JUNIOR, J. I.; CARMO, E. L.; NOGUEIRA JUNIOR, A. F. The field resistance of potato cultivars to foliar late blight and its relationship with foliage maturity type and skin type in Brazil. Australasian Plant Pathology, v. 41, n. 2, p. 139-155,
2012. DOI: $10.1007 / \mathrm{s} 13313-011-0102-6$

DUARTE, H. S. S.; ZAMBOLIM, L.; RODRIGUES, F. A.; PAUL, P. A.; PADUA, J. G.; RIBEIRO JUNIOR, J. I.; NOGUEIRA JUNIOR, A. F.; ROSADO, A. W. Field resistance of potato cultivars to foliar early blight and its relationship with foliage maturity and tuber skin types. Tropical Plant Pathology, Brasília, v. 39, n. 4, p. 294306, 2014. DOI: $10.1590 /$ S1982-56762014000400004

DUARTE, H. S. S.; ZAMBOLIM, L.; RODRIGUES, F. Á.; RIOS, J. Á. Efeito do silicato de potássio isoladamente ou em mistura com fungicida no controle da requeima da batateira. Summa Phytopathologica, Botucatu, v. 34, n. 1, p. 68-70, 2008. DOI: 10.1590/ S0100-54052008000100014

FOOD AND AGRICULTURE ORGANIZATION - FAO. 2019. Available at: http://www.fao.org/faostat/en/\#data/ QC. Acessed at: 27 jun. 2019.

FRY, W. E. Integrated control of potato late blight: effects of polygenic resistance and techniques of timing fungicide applications. Phytopathology, Saint Paul, v. 67, n. 1 , p. 415-420, 1977. DOI: 10.1094/Phyto-67-415

GLEASON, M. L.; MACNAB, A. A.; PITBLADO, R. E.; RICKER, M. D.; EAST, D. A.; LATIN, R. X. Disease-warning systems for processing tomatoes in eastern North America: are we there yet? Plant Disease, Saint Paul, v. 79, n. 2, p. 113-121, 1995. DOI: 10.1094/ PD-79-0113

GUENTHNER, J. F.; WIESE, M. V.; PAVLISTA, A. D.; SIECZKA, J. B.; WYMAN, J. Assessment of pesticide use in the US potato industry. American Journal of Potato Research, v. 76, n. 1, p. 25-29, 1999. DOI: 10.1007/ BF02853554

JAMES, W. C. An illustrated series of assessment keys for plant disease, their preparation and usage. Canadian Plant Disease Survey, v. 51, n. 2, p. 39-65, 1971.

JOHNSON, K. B.; TENG, P. S. Coupling a disease progress model for early-blight to model of potato growth. Phytopathology, Saint Paul, v. 80, n. 1, p. 416425, 1990. DOI: 10.1094/Phyto-80-416

KRANZ, J. The methodology of comparative epidemiology. In: KRANZ, J.; ROTEM, J. Experimental techniques in plant disease epidemiology. Heidelberg: Springer-Verlag, 1988. Cap. 20, p. 279-290.

LIMA, M. A.; MAFFIA, L. A.; BARRETO, R. W.; MIZUBUTI, E. S. G. Phytophthora infestans in a subtropical region: survival on tomato debris, temporal dynamics of airborne sporangia and alternative hosts. Plant Pathology, Chichester, v. 58, n. 1 p. 87-99, 2009. DOI: $10.1111 / j .1365-3059.2008 .01951 . x$ 
MAZIERO, J. M. N.; MAFFIA, L. A.; MIZUBUTI, E. S. G. Effects of temperature on events in the infection cycle of two clonal lineages of Phytophthora infestans causing late blight on tomato and potato in Brazil. Plant Disease, Saint Paul, v. 93, n. 5, p. 459-466, 2009. DOI: 10.1094/ PDIS-93-5-0459

MELO, P. C. T.; GRANJA, N. P.; MIRANDA FILHO, H. S.; SUGAWARA, A. C.; OLIVEIRA, R. F. Análise do crescimento da cultivar de batata Ágata. Batata Show, Itapetininga, v. 8, n. 8, p. 16-17, 2003.

MIZUBUTI, E. S. G. Requeima ou mela da batata e do tomate. In: LUZ, E. D. N.; SANTOS, A. F.; MATSUOKA, K.; BEZERRA, J. L. Doenças causadas por Phytophthora no Brasil. Campinas: Livraria Editora Rural, 2001. Cap. 8, p. 100-174.

OLIVEIRA, S. A. S. Genetic structure, aggressiveness and fungicide sensitivity of Phytophthora infestans populations from the south and southeast regions of Brazil. 2010. Tese (Doutorado em Fitopatologia) Universidade Federal de Viçosa, Viçosa, MG.

RODRIGUES, T. T. M. S.; BERBEE, M. L.; SIMMONS, E. G.; CARDOSO, C. R.; REIS, A.; MAFFIA, L. A.; MIZUBUTI, E. S. G. First report of Alternaria tomatophila and $A$. grandis causing early blight on tomato and potato in Brazil. New Disease Report, v. 22. n. 28, p. 28-28, 2010. DOI: 10.5197/j.2044-0588.2010.022.028

ROTEM, L. The genus Alternaria: biology, epidemiology, and pathogenicity. Saint Paul: APS Press, 1994, 326 p.
SHANER, G.; FINNEY, R. E. The effect of nitrogen fertilization on the expression of slow-mildewing resistance in knox wheat. Phytopathology, Saint Paul, v. 67 , n. 8 , p. 1051-1056, 1977. DOI: $10.1094 /$ Phyto-67-1051

SHTIENBERG, D.; BLACHINSKY, D.; BEN-HADOR, G.; DINOOR, A. Effects of growing season and fungicide type on the development of Alternaria solani and on potato yield. Plant Disease, Saint Paul, v. 80, n. 9, p. 994998, 1996. DOI: 10.1094/PD-80-0994

SHUMAN, J. L.; CHRIST, B. J. Integrating a hostresistance factor into the Fast system to forecast early blight of potato. American Journal of Potato Research, v. 82 , n. 9, p. $9-19,2005$. DOI: 10.1007/BF02894915

SIMMONS, E. G. Alternaria themes and variations (244-286) species on solanaceae. Mycotaxon, v. 75, n. 1, p. $1-115,2000$.

SUASSUNA, N. D.; MAFFIA, L. A.; MIZUBUTI, E. S. G. Aggressiveness and host specificity of Brazilian isolates of Phytophthora infestans. Plant Pathology, Chichester, v. 53, n. 4, p. 405-413, 2004. DOI: 10.1111/j.1365-3059.2004.01043.x

TÖFOLI， J. G.; DOMINGUES， R. J.; GARCIA JUNIOR, O.; KUROZAWA, C. Controle da pinta preta do tomateiro por fungicidas e seus impactos na produção. Summa Phytopathologica, Botucatu, v. 29, n. 3, p. 225233, 2003.

ZAMBOLIM, L.; DUARTE, H. S. S.; ZAMBOLIM, E. $\mathrm{M}$. Medidas integradas de controle das doenças fúngicas da batata. In: ZAMBOLIM, L. Produção integrada da batata. Visconde do Rio Branco: Suprema Gráfica, 2011. Cap. 11, p. 411-438. 